(Jurnal Statistika dan Matematika)

\title{
ANALISIS PENGENDALIAN KUALITAS PRODUK ROTI MELALUI KARTU KENDALI PROPORSI \\ (Studi Kasus: CV. Spesial Bakery)
}

\author{
Aden $^{1}$ dan Tabah Heri Setiawan ${ }^{2}$ \\ Program Studi Matematika, FMIPA - UNPAM \\ 1dosen00527@unpam.ac.id \\ 2dosen00685@unpam.ac.id
}

\begin{abstract}
The control card is a tool for controlling the quality of an industrial product. The credit card used in this study is the proportion control card. The purpose of this study are: (1) Knowing the form of the proportion control card that is controlled by the data of bread production. (2) Knowing the percentage of dominant defects that occur from bread production. Quantitative methods are used in this study. Data is taken from survey results. Data analysis was carried out using 4 (four) stages namely data collection, data analysis, data presentation and conclusion drawing. The result of this study is that the controlled control card has 6 control cards in accordance with the number of products produced and the dominant defect that occurs in production is the defect of mocca sandwich production with a percentage of $26.84 \%$.
\end{abstract}

Keywords: Quality Control Statistics, Proportions, Control Cards

\begin{abstract}
ABSTRAK
Kartu kendali merupakan alat untuk mengendalian kualitas sebuah produk industri. Kartu kerdali yang digunakan pada penelitian ini yaitu kartu kendali proporsi. Tujuan dari penelitian ini yaitu: (1) Mengetahui bentuk kartu kendali proporsi yang terkendali data produksi roti. (2) Mengetahui bentuk persentase kecacatan dominan yang terjadi dari produksi roti. Metode kuantitatif digunakan dalam penelitian ini. Data diambil dari hasil survei. Analisis data dilakukan dengan mengunakan 4 (empat) tahapan yaitu pengumpulan data, analisis data, penyajian data dan penarikan kesimpulan. Hasil penelitian ini yaitu kartu kendali yang terkendali terdapat 6 kartu kendali sesuai dengan jumlah produk yang diproduksi dan kecacatan dominan yang terjadi pada produksi yaitu pada kecacatan produksi roti isi mocca dengan persentase $26,84 \%$.
\end{abstract}

Kata Kunci: Statistik Pengendalian Kualitas, Proporsi, Kartu Kendali

\section{PENDAHULUAN}

\subsection{Latar Belakang Masalah}

Kualitas sebuah sebuah produk pada industri bergantung kepada bagaimana mengendalikannya ketika sebelum proses, ketika proses produksi dan setelah proses produksi atau pendistribusian produk ke berbagai distributor atau bahkan konsumen. Produk yang akan diproduksi tidak mempunyai patokan yang jelas atau detilisasi suatu 


\section{STATMAT}

(Jurnal Statistika dan Matematika)

produk yang tidak baku akan mengakibatkan terjadinya banyak variasi. Ukuran produk yang tidak jelas akan mengakibatkan kesulitan dalam produksi. Bentuk yang tidak pasti akan membentuk suatu produk yang kurang baik. Warna yang tidak ditentukan ukuran yang jelas pasti akan mengakibatkan perbedaan yang akan signifikan.

Produksi yang berlangsung tidak dikontrol dengan baik akan mengakibatkan terjadinya banyak variasi barang yang tidak terkendali. Bahan baku yang tidak terkontrol akan mengakibatkan kerugian yang besar dikarenakan akan banyak bahan baku yang terbuang dengan sia-sia. Ketersediaan bahan baku yang kurang mencukupi akan mengakibatkan keterlambatan produksi sebuah barang. Akhirnya konsumen akan mengalami kekecewaan ketika pesanan barang atau pruduk barangnya terlambat tidak sesuai dengan jadwal yang ditentukan.

Produksi yang tidak menggunakan alat kendali control kualitas khususnya bagi QC( quality control) akan mengakibatkan lolosnya barang yang terkadang ada kecatan yang ada pada sebuah produk. Terlebih bagi seorang kepala gudang ketika tidak mempunyai alat pengendali produk ketika menerima produk dari bagian produksi akan mengakibatkan permasalahan yang akan berlanjut ketika barang tetap lolos ke bagian gudang. Karena produk yang telah lolos ke bagian gudang maka akan siap untuk dikirim ke bagian distributor atau bahkan ke konsumen.

Produksi suatu produk memerlukan ketelitian dalam memproduksi baik dari segi ukuran, bentuk, maupun paking sebuah produk yang akan dipasarkan. Produksi yang baik akan menjadikan kualitas produk akan lebih baik dibanding produksi yang tidak dikendalikan dengan konstan dengan menggunakan sebuah alat. Alat pengendalian kualitas dapat berbentuk diagram garis, diagram batang, diagram pareto, kartu kendali, dan lain-lain. Salah satu metode pengendalian yang telah disebutkan yaitu kartu kendali dimana kartu kendali terdapat dua bagian ayang utama yaitu kartu kendali produk dan atribut. Kartu kendali produk terdiri dari kartu kendali rata-rata, kartu kendali jangkauan, dan kartu kendali simpangan baku atau standar deviasi. Sedangkan kartu kendali atribut terdapat dua bentuk yaitu bentuk kartu kendali proprsi dan kartu kendali cacat.

Kartu kendali proporsi yaitu kartu kendali yang menggunakan perhitungan statistik yang berbentuk proporsi dengan membandingkan jumlah kecacatan atau kesalahan dari produksi yang dilakukan dalam periode tertentu. Sehingga pengendalian dengan 
STATMAT

(Jurnal Statistika dan Matematika)

mengunakan kartu kendali proporsi ini akan mengendalikan produk hasil produksi industri dalam waktu yang singkat atau waktu yang panjang.

Sesuai dengan latar belakang yang telah disebutkan di atas, maka peneliti akan melakukan penelitian yang berjudul "Analisis Pengendalian Kualitas Produk Roti Melalui Kartu Kendali Proporsi ( Studi Kasus: CV. Spesial)““.

\subsection{Rumusan Masalah}

Berdasarkan identifikasi dan batasan masalah yang telah diuraikan di atas, selanjutnya perumusan masalah dalam penelitian ini adalah:

1) Bagaimana bentuk kartu kendali proporsi yang terkendali data produksi roti?

2) Bagaimana bentuk persentase kecacatan dominan yang terjadi dari produksi roti?

\subsection{Tujuan Penelitian}

Dari rumusan masalah di atas maka penelitian ini mempunyai tujuan:

1) Mengetahui bentuk kartu kendali proporsi yang terkendali data produksi roti.

2) Mengetahui bentuk persentase kecacatan dominan yang terjadi dari produksi roti.

\subsection{Manfaat Penelitian}

Manfaat praktis penelitian ini bagi peneliti dan mahasiswayaitu:

1) Mendalami aplikasi dari statistik pengendalian kualitas.

2) Menjadikan rujukan penelitian yang berbasis kepada statistik pengendalian kualitas. Manfaat praktis bagi industri yaitu:

1) Mengetahui bentuk persentase kecacatan yang paling dominan pada produksi roti sehingga dapat menentukan langkah yang terbaik untuk perbaikan produksi tahap selanjutnya atau produksi berkelanjutan.

2) Dapat menentukan kartu kendali yang terkendali dalam produksi produk.

3) Menyiapkan bahan baku yang lebih terkontrol dengan kartu kendali.

4) Mempunyai kualitas produksi yang terkendali.

\section{METODOLOGI PENELITIAN}

\subsection{Kartu Kendali Proporsi}

Pengendalian kualitas dengan menggunakan peta kontrol dapat digunakan sebagai alat perbaikan kualitas, sehingga dapat meningkatkan kualitas produk yang dihasilkan dan memberikan keuntungan karena produk yang dihasilkan 
STATMAT

(Jurnal Statistika dan Matematika)

mempunyai kualitas yang baik (Idris, 2016: 66). Proporsi yaitu perbandingan produk barang yang cacat dengan banyaknya produk yang diamati. Lambang dari proporsi itu sendiri adalah p. Sehingga pada saat sampel diamati maka kita akan tahu seberapa persen produk yang gagal. Kriteria atribut dari kartu kendali proporsi ini adalah diterima (baik) atau ditolak (cacat).

Perumusan untuk proporsi adalah :

$\mathrm{p}=\frac{c_{i}}{A_{i}}$

Dimana :

$\mathrm{P}=$ proporsi

$\mathrm{C}_{\mathrm{i}}=$ banyaknya (ditolak)cacat pada pengamatan periode ke-i

$A_{i}=$ banyaknya pengamatan pada periode ke-i

Langkah - langkah untuk mebuat kartu kendali proporsi adalah sebagai berikut :

1) Menghitung proporsi tiap periode sampel dengan menggunakan perumusan 2.17.

2) Menghitung simpangan baku dari proporsi tiap periode pengamatan dengan perumusan adalah sebagai berikut :

$$
\sigma_{p}=\sqrt{\frac{p \prime\left(1-p^{\prime}\right)}{n}}
$$

Dimana :

$\mathrm{p}^{\prime}=\mu_{p}=$ rata - rata dari proporsi data populasi

$\boldsymbol{\mu}_{\boldsymbol{p}}=\frac{\sum \boldsymbol{p}_{i}}{\boldsymbol{N}}$

Dimana :

$\mathrm{p}_{\mathrm{i}}=$ proporsi tiap periode pengamatan ke- $\mathrm{i}$

$\mathrm{N}$ = banyaknya periode pengamatan

3) Menentukan limit kontrol bawah dan limit kontrol atas. Dimana untuk menentukan LKA dan LKB adalah sebagai berikut :

Jika Data Yang Diamati Per Periode Sama Yaitu n

Sedangkan untuk titik sentralnya atau titik tengah adalah $\bar{p}$. 


$$
\begin{aligned}
& \mathrm{LKA}=\bar{p}+3 \sqrt{\frac{\bar{p}(1-\bar{p})}{n}} \\
& \mathrm{LKB}=\bar{p}-3 \sqrt{\frac{\bar{p}(1-\bar{p})}{n}}
\end{aligned}
$$

Dimana :

$\bar{p}=\frac{\sum p_{i}}{n}$

$\bar{p}=$ rata - rata proporsi

Jika Data Yang Diamati Per Periode berbeda yaitu

$$
\begin{aligned}
\mathrm{LKA} & =\bar{p}+3 \sqrt{\frac{\bar{p}(1-\bar{p})}{n_{i}}} \\
\mathrm{LKB} & =\bar{p}-3 \sqrt{\frac{\bar{p}(1-\bar{p})}{n_{i}}}
\end{aligned}
$$

Dimana :

$$
\begin{aligned}
& \bar{p}=\frac{\sum p_{i}}{n_{i}} \\
& \bar{p}=\text { rata }- \text { rata proporsi }
\end{aligned}
$$

\subsection{Metode Penelitian}

Metode penelitian kuantitatif dapat diartikan sebagai metode penelitian yang berlandaskan pada pilsafat positivisme, digunakan untuk meneliti pada populasi dan sampel tertentu, pengumpulan data menggunakan instrumen penelitian, analisis data bersifat kuantitatif atau statistik, dengan tujuan untuk menguji hipotesis yang telah ditetapkan (Sugiyono: 2016: 8). Metode penelitian yang digunakan pada penelitian ini yaitu penelitian survei.

\subsection{Metode Penentuan Sampel}

Totalitas semua nilai yang mungkin, hasil menghitung maupun pengukuran, kuantitatif maupun kualitatif mengenai karakteristik tertentu dari semua anggota kumpulan yang lengkap dan jelas yang ingin dipelajari sifat-sifatnya dinamakan dengan populasi (Sudjana: 2005: 6). Populasi diambil sampel yang proporsional untuk dilakakukan penelitian. Sampel yaitu bagian dari populasi untuk dijadikan sebagai bahan penelaahanndengan harapan contoh yang diambil dari populasi tersebut dapat mewakili terhadap populasi ( Andi Supangat: 2007: 4). Sampel adalah bagian dari jumlah dan 
STATMAT

(Jurnal Statistika dan Matematika)

karakteristik yang dimiliki populasi.( Sugiyono: 2012: 62). Sampel merupakan bagian dari populasi yang diambil sebagian secara proporsional sesuai dengan metode yang telah ditetapkan oleh peniliti dalam menentukan jumlah sampel.. Untuk mendapatkan sampel digunakan teknik sampel terstruktur. Data sampel pada penelitian ini data yang diambil sebanyak 20 hari kerja terhitung sejak tanggal 1 Februari 2017 sampai dengan 28 Februari 2018.

\subsection{Metode Pengolahan Data}

Pengolahan data pada penelitian ini dilakukan dalam bentuk manual dengan bantuan Excel 2016. Langkah-langkah perhitungan pengolahan data dalam penelitian ini yaitu :

1. Menghitung proporsi untuk setiap periode data

2. Menghitung rata-rata dari proporsi yang telah diperhitungkan pada langkah ke1 yang akan dijadikan sebagai titik sntral pada kartu kendali proporsi.

3. Menghitung limit control atas (LKA)

4. Menghitung limit control bawah (LKB), jika hasil LKB bernilai negative maka dijadikan 0 karena tidak kecacatan yang hasilnya negative jika tidak cacat atau 0 maka cacat atau bernilai 1 .

5. Membuat kartu kendali proporsi dengan menggunakan bantuan Excel 2016.

6. Mengevaluasi hasil kartu kendali proporsi dengan syarat tidak ada yang keluar dari batas kendali baik kendali atas maupun bawah.

7. Jika terdapat data yang keluar dari batas kendali maka perlu dievaluasi dan data yang keluar dihilangkan kemudian menghitung kembali keperhitungan langkah ke-2 sampai dengan akhir.

8. Jika sudah tidak terdapat lagi data yang keluar dari kartu kendali maka dikategorikan kartu kendali proporsi yang telah terkendali.

9. Membuat kesimpulan dari analisis data yang telah diselesaikan.

\section{HASIL DAN PEMBAHASAN}

\subsection{Data Penelitian}

Berikut data hasil penelitian hasil survei dari CV. Spesial Bakery. 


\section{STATMAT}

(Jurnal Statistika dan Matematika)
P-ISSN: 2655-3724

STATMAT (Jurnal Statistika dan Matematika), Vol. 1, No. 1, Januari 2019 Halaman: 25-43

@ Prodi S-1 Matematika FMIPA Unpam

Tabel 3.1 Tabel Data Penelitian

\begin{tabular}{|c|c|c|c|c|c|c|c|c|c|c|c|c|c|c|}
\hline \multirow{3}{*}{ PERIODE KE- } & \multicolumn{12}{|c|}{ NAMA PRODUKSI } & \multirow{3}{*}{ TOTAL PRODUKSI } & \multirow{3}{*}{ TOTAL CACAT } \\
\hline & \multicolumn{2}{|c|}{ COKLAT } & \multicolumn{2}{|c|}{ KEJU } & \multicolumn{2}{|c|}{ KELAPA } & \multicolumn{2}{|c|}{ MOCCA } & \multicolumn{2}{|c|}{ PIA KACANG HIJAU } & \multicolumn{2}{|c|}{ PIA COKLAT } & & \\
\hline & PRODUKSI & CACAT & PRODUKSI & CACAT & PRODUKSI & CACAT & PRODUKSI & CACAT & PRODUKSI & CACAT & PRODUKS & CACAT & & \\
\hline 1 & 425 & 2 & 150 & 1 & 200 & 1 & 340 & 3 & 40 & 2 & 10 & 1 & 1165 & 10 \\
\hline 2 & 300 & 3 & 175 & 1 & 175 & 2 & 260 & 2 & 28 & 1 & 7 & 0 & 945 & 9 \\
\hline 3 & 100 & 1 & 75 & 0 & 125 & 1 & 100 & 1 & 35 & 1 & 5 & 0 & 440 & 4 \\
\hline 4 & 325 & 2 & 150 & 2 & 175 & 1 & 140 & 2 & 27 & 1 & 5 & 0 & 822 & 8 \\
\hline 5 & 200 & 1 & 125 & 1 & 125 & 2 & 190 & 1 & 28 & 1 & 8 & 0 & 676 & 6 \\
\hline 6 & 425 & 3 & 175 & 1 & 175 & 2 & 340 & 3 & 28 & 1 & 2 & 0 & 1145 & 10 \\
\hline 7 & 275 & 2 & 175 & 1 & 125 & 1 & 385 & 5 & 37 & 1 & 8 & 0 & 1005 & 10 \\
\hline 8 & 275 & 2 & 325 & 3 & 250 & 2 & 300 & 3 & 27 & 1 & 3 & 0 & 1180 & 11 \\
\hline 9 & 200 & 1 & 125 & 2 & 250 & 3 & 310 & 2 & 30 & 1 & 10 & 0 & 925 & 9 \\
\hline 10 & 250 & 3 & 175 & 1 & 150 & 1 & 250 & 2 & 25 & 1 & 5 & 0 & 855 & 8 \\
\hline 11 & 225 & 2 & 125 & 1 & 150 & 2 & 235 & 1 & 25 & 1 & 5 & 0 & 765 & 7 \\
\hline 12 & 250 & 1 & 150 & 2 & 175 & 2 & 250 & 0 & 35 & 1 & 5 & 0 & 865 & 6 \\
\hline 13 & 225 & 2 & 150 & 2 & 175 & 1 & 290 & 1 & 34 & 1 & 8 & 0 & 882 & 7 \\
\hline 14 & 225 & 1 & 125 & 1 & 225 & 1 & 315 & 4 & 25 & 1 & 5 & 0 & 920 & 8 \\
\hline 15 & 225 & 3 & 150 & 1 & 200 & 1 & 200 & 2 & 22 & 1 & 3 & 0 & 800 & 8 \\
\hline 16 & 150 & 1 & 125 & 1 & 50 & 0 & 125 & 1 & 36 & 1 & 4 & 0 & 490 & 4 \\
\hline 17 & 200 & 1 & 200 & 3 & 175 & 1 & 315 & 3 & 30 & 1 & 5 & 0 & 925 & 9 \\
\hline 18 & 275 & 1 & 150 & 2 & 150 & 2 & 245 & 3 & 24 & 0 & 6 & 0 & 850 & 8 \\
\hline 19 & 275 & 2 & 125 & 1 & 175 & 2 & 245 & 2 & 30 & 1 & 6 & 0 & 856 & 8 \\
\hline 20 & 200 & 2 & 175 & 2 & 200 & 2 & 245 & 1 & 30 & 1 & 5 & 0 & 855 & 8 \\
\hline 21 & 225 & 3 & 150 & 1 & 200 & 2 & 180 & 1 & 16 & 0 & 5 & 0 & 776 & 7 \\
\hline 22 & 225 & 2 & 150 & 1 & 200 & 2 & 245 & 2 & 30 & 1 & 5 & 0 & 855 & 8 \\
\hline 23 & 275 & 1 & 125 & 2 & 175 & 1 & 245 & 3 & 33 & 1 & 7 & 0 & 860 & 8 \\
\hline 24 & 225 & 2 & 150 & 1 & 200 & 2 & 315 & 3 & 35 & 1 & 7 & 0 & 932 & 9 \\
\hline
\end{tabular}

Data dalam bentuk persentase untuk setiap produk dari CV. Spesial Bakery .

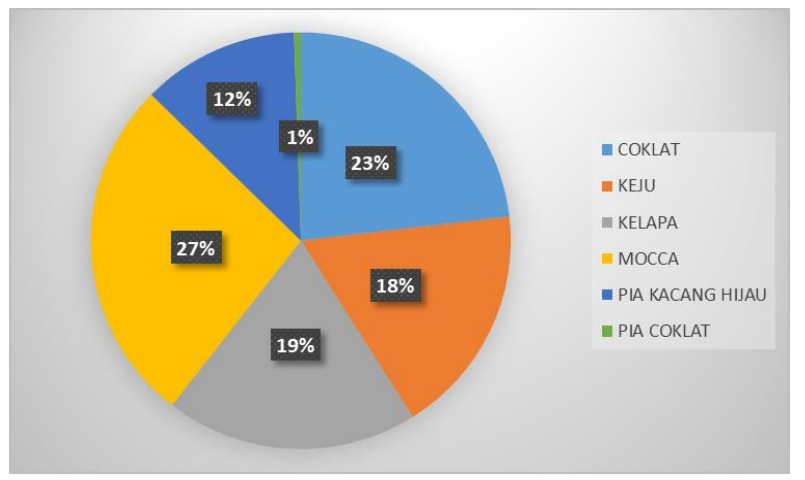

Gambar 3.1 Sebaran Data Kecacatan

\subsection{Kartu Kendali untuk Produk Roti Isi Coklat}

a. Menentukan nilai proporsi setiap periode pada produk roti isi coklat yaitu 


$$
p_{1}=\frac{x_{1}}{n_{1}}=\frac{2}{425}=0,00471
$$

Dan seterusnya sampai dengan periode ke-25, terlihat pada tabel 4.3.

b. Menentukan nilai rata-rata proporsi yaitu

$$
\begin{gathered}
\bar{p}=\sum \frac{p_{i}}{n} \\
\bar{p}=0,00756
\end{gathered}
$$

c. Menentukan nilai LKA yaitu

$$
\begin{gathered}
L K A_{1}=\bar{p}+3 \sqrt{\frac{\bar{p}(1-\bar{p})}{n_{i}}} \\
L K A_{1}=0,00756+3 \sqrt{\frac{0,00756(1-00,0756)}{425}} \\
L K A_{1}=0,02016
\end{gathered}
$$

Dan seterusnya sampai dengan data yang ke-24

d. Menentukan nilai LKB yaitu

$$
\begin{gathered}
L K B_{1}=\bar{p}-3 \sqrt{\frac{\bar{p}(1-\bar{p})}{n_{i}}} \\
L K B=0,00756-3 \sqrt{\frac{0,00756(1-00,0756)}{425}} \\
L K B_{1}=-0,0505
\end{gathered}
$$

Karena nilai kecacatan tidak mungkin negatif maka LKB dijadikan 0 dan seterusnya sampai dengan data yang ke-24

e. Membuat kartu kendali proporsi untuk produk roti isi coklat 


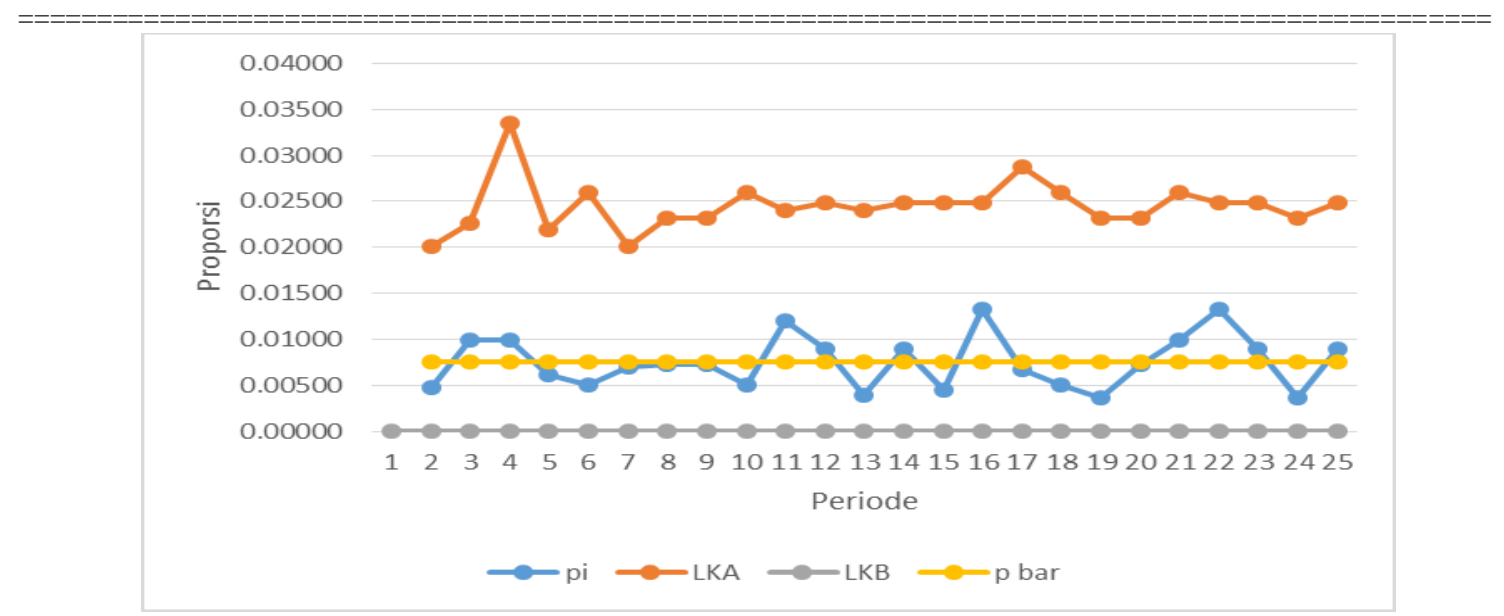

Gambar 3.2 Kartu Kendali Produk Roti Isi Coklat

f. Evaluasi kartu kendali

Kartu kendali produk roti isi coklat sesuai pada gambar 3.2 terlihat bahwa semua proporsi kecacatan setiap periode dari periode ke-1 hingga periode ke-25 terdapat pada area di atas LKB dan di bawah LKA. Kartu kendali produk roti isi coklat terkategori sudah terkendali sehingga kartu kendali produk isi coklat yang terkendali yang dapat dijadikan ukuran untuk perusahaan CV Spesial bakery.

\subsection{Kartu Kendali}

\subsubsection{Kartu Kendali untuk Produk Roti Isi Keju}

a. Menentukan nilai proporsi setiap periode pada produk roti isi keju yaitu

$$
p_{1}=\frac{x_{1}}{n_{1}}=\frac{1}{150}=0,00667
$$

Dan seterusnya sampai dengan periode ke-25, terlihat pada tabel 4.4.

b. Menentukan nilai rata-rata proporsi yaitu

$$
\begin{gathered}
\bar{p}=\sum \frac{p_{i}}{n} \\
\bar{p}=0,00905
\end{gathered}
$$

c. Menentukan nilai LKA yaitu

$$
L K A_{1}=\bar{p}+3 \sqrt{\frac{\bar{p}(1-\bar{p})}{n_{i}}}
$$




$$
\begin{gathered}
L K A_{1}=0,00905+3 \sqrt{\frac{0,00905(1-0,00905)}{150}} \\
L K A_{1}=0,03225
\end{gathered}
$$

Dan seterusnya sampai dengan data yang ke-24

g. Menentukan nilai LKB yaitu

$$
\begin{gathered}
L K B_{1}=\bar{p}-3 \sqrt{\frac{\bar{p}(1-\bar{p})}{n_{i}}} \\
L K B_{1}=0,00905-3 \sqrt{\frac{0,00905(1-0,00905)}{150}} \\
L K B_{1}=-0,01415
\end{gathered}
$$

Karena nilai kecacatan tidak mungkin bernilai negatif maka LKB dijadikan 0 dan seterusnya sampai dengan data yang ke-24.

d. Membuat kartu kendali proporsi untuk produk roti isi keju

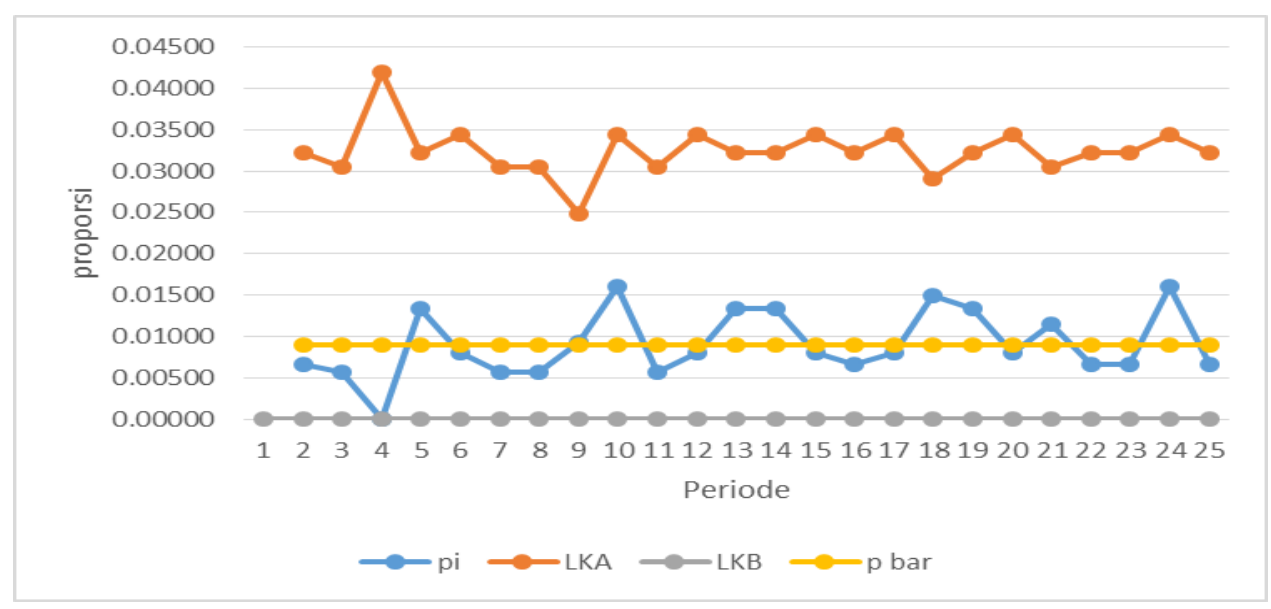

Gambar 3.3 Kartu Kendali Produk Roti Isi Keju

e. Evaluasi kartu kendali

Kartu kendali produk roti isi keju sesuai pada gambar 3.3 terlihat bahwa semua proporsi kecacatan setiap periode dari periode ke-1 hingga periode ke-25 terdapat pada area di atas LKB dan di bawah LKA. Kartu kendali produk roti isi keju terkategori sudah terkendali sehingga kartu kendali produk isi keju yang terkendali yang dapat dijadikan ukuran untuk perusahaan CV Spesial bakery. 
(Jurnal Statistika dan Matematika)

\subsubsection{Kartu Kendali untuk Produk Roti Isi Kelapa}

a. Menentukan nilai proporsi setiap periode pada produk roti isi kelapa yaitu

$$
p_{1}=\frac{x_{1}}{n_{1}}=\frac{1}{200}=0,00500
$$

Dan seterusnya sampai dengan periode ke-25, terlihat pada tabel 4.5.

b. Menentukan nilai rata-rata proporsi yaitu

$$
\begin{gathered}
\bar{p}=\sum \frac{p_{i}}{n} \\
\bar{p}=0,00868
\end{gathered}
$$

c. Menentukan nilai LKA yaitu

$$
\begin{gathered}
L K A_{1}=\bar{p}+3 \sqrt{\frac{\bar{p}(1-\bar{p})}{n_{i}}} \\
L K A_{1}=0,00868+3 \sqrt{\frac{0,00868(1-0,00868)}{200}} \\
L K A_{1}=0,02836
\end{gathered}
$$

Dan seterusnya sampai dengan data yang ke-24

h. Menentukan nilai LKB yaitu

$$
\begin{gathered}
L K B_{1}=\bar{p}-3 \sqrt{\frac{\bar{p}(1-\bar{p})}{n_{i}}} \\
L K B_{1}=0,00868-3 \sqrt{\frac{0,00868(1-0,00868)}{200}} \\
L K B_{1}=-0,01100
\end{gathered}
$$

Karena nilai kecacatan tidak mungkin bernilai negatif maka LKB dijadikan 0 dan seterusnya sampai dengan data yang ke-24.

d. Membuat kartu kendali proporsi untuk produk roti isi kelapa 
(Jurnal Statistika dan Matematika)

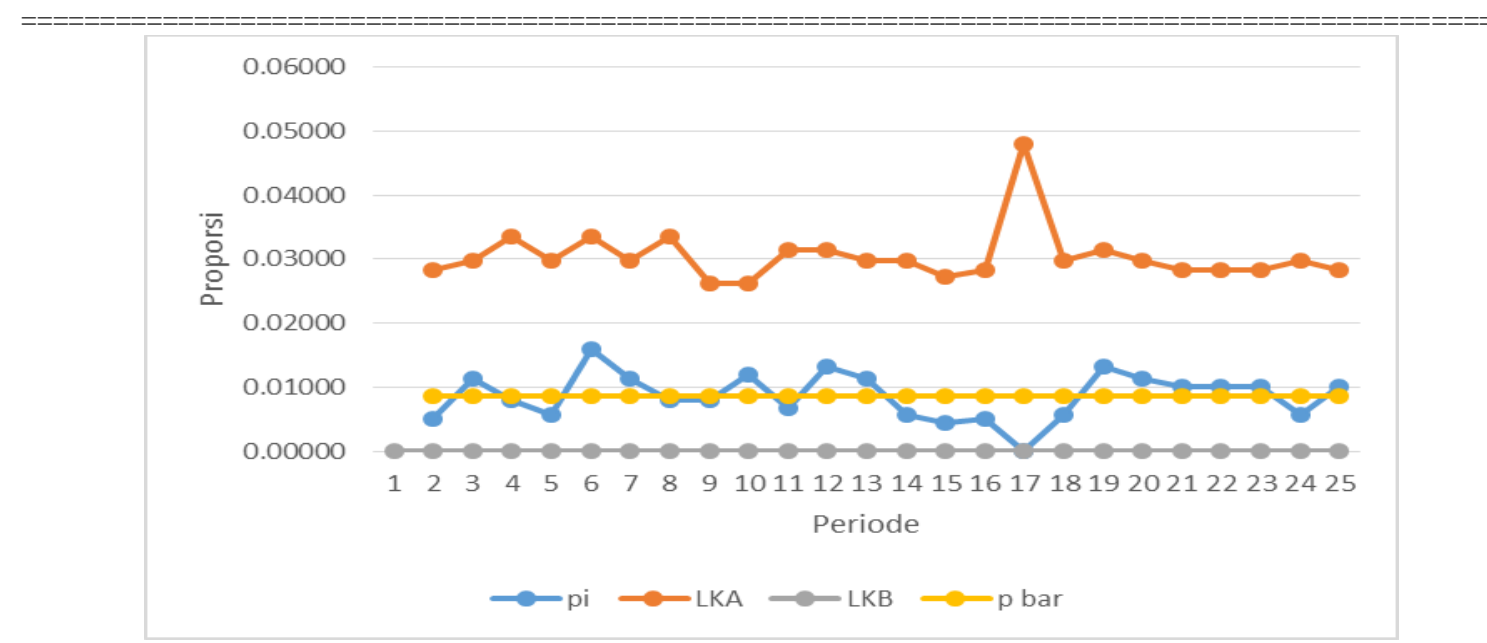

Gambar 3.4 Kartu Kendali Produk Roti Isi Kelapa

e. Evaluasi kartu kendali

Kartu kendali produk roti isi kelapa sesuai pada gambar 3.4 terlihat bahwa semua proporsi kecacatan setiap periode dari periode ke-1 hingga periode ke-25 terdapat pada area di atas LKB dan di bawah LKA. Kartu kendali produk roti isi kelapa terkategori sudah terkendali sehingga kartu kendali produk isi kelapa yang terkendali yang dapat dijadikan ukuran untuk perusahaan CV Spesial bakery.

\subsubsection{Kartu Kendali untuk Produk Roti Isi Mocca}

a. Menentukan nilai proporsi setiap periode pada produk roti isi Mocca yaitu

$$
p_{1}=\frac{x_{1}}{n_{1}}=\frac{3}{340}=0,00882
$$

Dan seterusnya sampai dengan periode ke-25, terlihat pada tabel 4.6.

b. Menentukan nilai rata-rata proporsi yaitu

$$
\begin{gathered}
\bar{p}=\sum \frac{p_{i}}{n} \\
\bar{p}=0,00834
\end{gathered}
$$

c. Menentukan nilai LKA yaitu

$$
\begin{gathered}
L K A_{1}=\bar{p}+3 \sqrt{\frac{\bar{p}(1-\bar{p})}{n_{i}}} \\
L K A_{1}=0,00834+3 \sqrt{\frac{0,00834(1-0,00834)}{340}}
\end{gathered}
$$




$$
L K A_{1}=0,02314
$$

Dan seterusnya sampai dengan data yang ke-24

i. Menentukan nilai LKB yaitu

$$
\begin{gathered}
L K B_{1}=\bar{p}-3 \sqrt{\frac{\bar{p}(1-\bar{p})}{n_{i}}} \\
L K B_{1}=0,00834-3 \sqrt{\frac{0,00834(1-0,00834)}{340}} \\
L K B_{1}=-0,00646
\end{gathered}
$$

Karena nilai kecacatan tidak mungkin bernilai negatif maka LKB dijadikan 0 dan seterusnya sampai dengan data yang ke-24.

d. Membuat kartu kendali proporsi untuk produk roti isi mocca

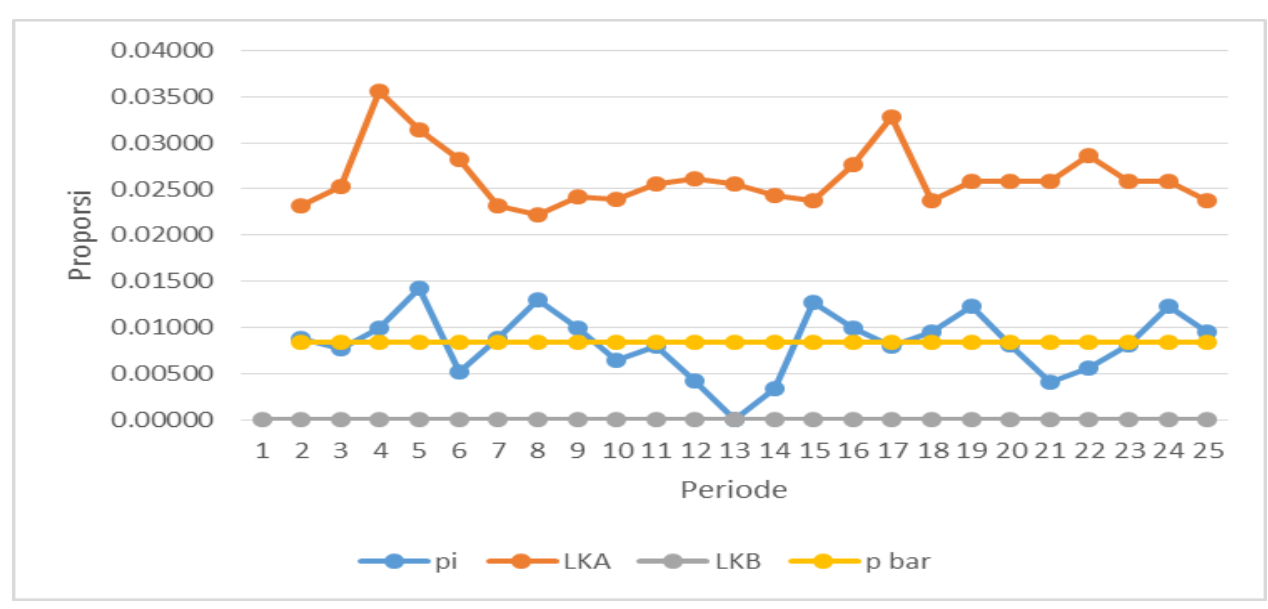

Gambar 3.5 Kartu Kendali Produk Roti Isi Mocca

e. Evaluasi kartu kendali

Kartu kendali produk roti isi kelapa sesuai pada gambar 3.5 terlihat bahwa semua proporsi kecacatan setiap periode dari periode ke-1 hingga periode ke-25 terdapat pada area di atas LKB dan di bawah LKA. Kartu kendali produk roti isi mocca terkategori sudah terkendali sehingga kartu kendali produk isi mocca yang terkendali yang dapat dijadikan ukuran untuk perusahaan CV Spesial Bakery.

\subsubsection{Kartu Kendali untuk Produk Roti PIA Kacang Hijau}

a. Menentukan nilai proporsi setiap periode pada produk roti PIA Kacang Hijau yaitu 


$$
p_{1}=\frac{x_{1}}{n_{1}}=\frac{2}{40}=0,05000
$$

Dan seterusnya sampai dengan periode ke-25, terlihat pada tabel 4.7.

b. Menentukan nilai rata-rata proporsi yaitu

$$
\begin{gathered}
\bar{p}=\sum \frac{p_{i}}{n} \\
\bar{p}=0,03182
\end{gathered}
$$

c. Menentukan nilai LKA yaitu

$$
\begin{gathered}
L K A_{1}=\bar{p}+3 \sqrt{\frac{\bar{p}(1-\bar{p})}{n_{i}}} \\
L K A_{1}=0,03182+3 \sqrt{\frac{0,03182(1-0,03182)}{340}} \\
L K A_{1}=0,11507
\end{gathered}
$$

Dan seterusnya sampai dengan data yang ke-24

d. Menentukan nilai LKB yaitu

$$
\begin{gathered}
L K B_{1}=\bar{p}-3 \sqrt{\frac{\bar{p}(1-\bar{p})}{n_{i}}} \\
L K B_{1}=0,03182-3 \sqrt{\frac{0,03182(1-0,03182)}{40}} \\
L K B_{1}=-0,05144
\end{gathered}
$$

Karena nilai kecacatan tidak mungkin bernilai negatif maka LKB dijadikan 0 dan seterusnya sampai dengan data yang ke-24.

e. Membuat kartu kendali proporsi untuk produk roti PIA Kacang Hijau 
(Jurnal Statistika dan Matematika)

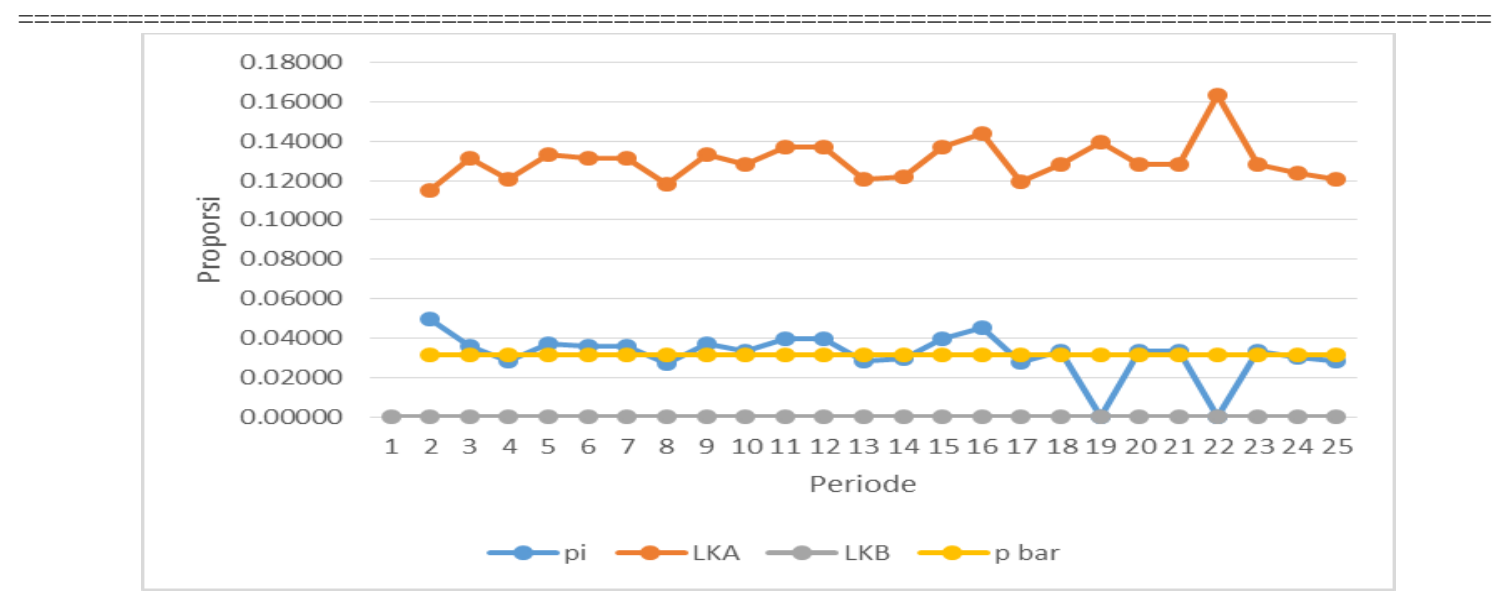

Gambar 3.6 Kartu Kendali Produk Roti PIA Kacang Hijau

f. Evaluasi kartu kendali

Kartu kendali produk roti isi kelapa sesuai pada gambar 3.6 terlihat bahwa semua proporsi kecacatan setiap periode dari periode ke-1 hingga periode ke-25 terdapat pada area di atas LKB dan di bawah LKA. Kartu kendali produk roti PIA Kacang Hijau terkategori sudah terkendali sehingga kartu kendali produk PIA Kacang Hijau yang terkendali yang dapat dijadikan ukuran untuk perusahaan CV Spesial Bakery.

\subsubsection{Kartu Kendali untuk Produk PIA Coklat}

a. Menentukan nilai proporsi setiap periode pada produk roti PIA Coklat yaitu

$$
p_{1}=\frac{x_{1}}{n_{1}}=\frac{1}{10}=0,10000
$$

Dan seterusnya sampai dengan periode ke-25, terlihat pada tabel 4.7.

b. Menentukan nilai rata-rata proporsi yaitu

$$
\begin{gathered}
\bar{p}=\sum \frac{p_{i}}{n} \\
\bar{p}=0,00417
\end{gathered}
$$

c. Menentukan nilai LKA yaitu

$$
\begin{gathered}
L K A_{1}=\bar{p}+3 \sqrt{\frac{\bar{p}(1-\bar{p})}{n_{i}}} \\
L K A_{1}=0,00417+3 \sqrt{\frac{0,00417(1-0,00417)}{10}}
\end{gathered}
$$




$$
L K A_{1}=0,06528
$$

Dan seterusnya sampai dengan data yang ke-24

d. Menentukan nilai LKB yaitu

$$
\begin{gathered}
L K B_{1}=\bar{p}-3 \sqrt{\frac{\bar{p}(1-\bar{p})}{n_{i}}} \\
L K B_{1}=0,00417-3 \sqrt{\frac{0,00417(1-0,00417)}{10}} \\
L K B_{1}=-0,05694
\end{gathered}
$$

Karena nilai kecacatan tidak mungkin bernilai negatif maka LKB dijadikan 0 dan seterusnya sampai dengan data yang ke-24.

e. Membuat kartu kendali proporsi untuk produk roti PIA Coklat

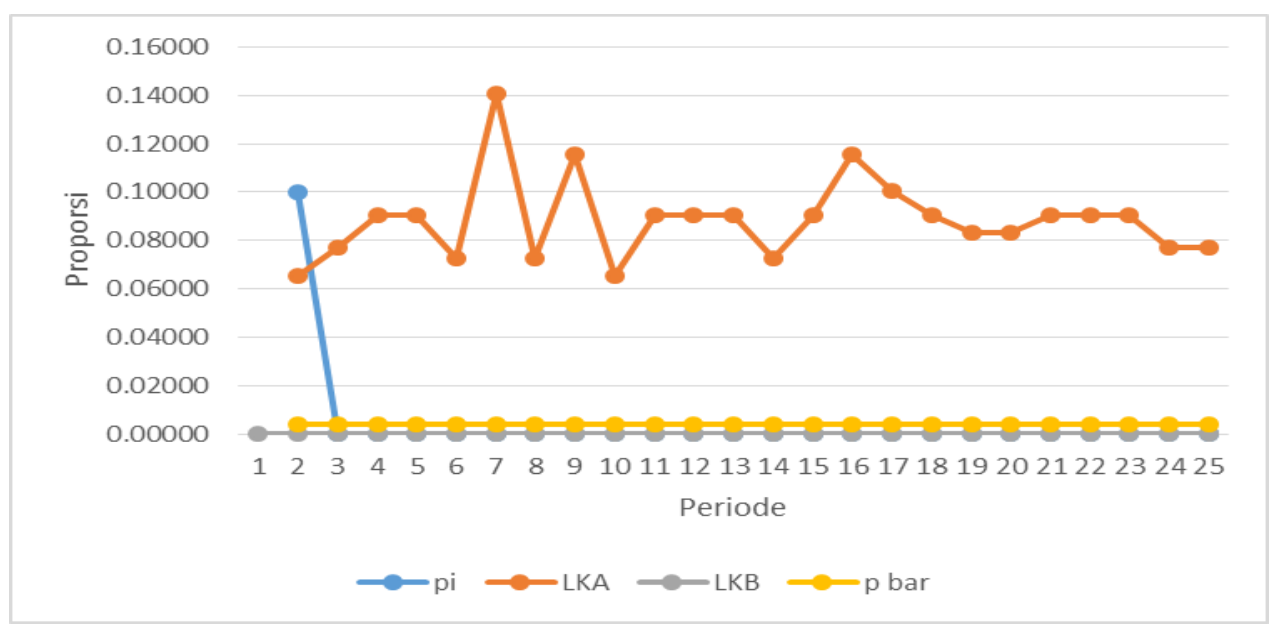

Gambar 3.7 Kartu Kendali Produk Roti PIA Coklat

f. Evaluasi kartu kendali

Kartu kendali produk roti isi kelapa sesuai pada gambar 3.7 terlihat bahwa semua proporsi kecacatan setiap periode dari periode ke-1 hingga periode ke-25 terdapat pada area di atas LKB dan di bawah LKA. Kartu kendali produk roti PIA Coklat terkategori sudah terkendali sehingga kartu kendali produk PIA Coklat yang terkendali yang dapat dijadikan ukuran untuk perusahaan CV Spesial Bakery.

\subsection{Pembahasan}

\subsubsection{Kartu Kendali yang Terkendali}


(Jurnal Statistika dan Matematika)

Perhitungan dan pembuatan kartu kendali proporsi untuk produk roti berbagaimbentuk yaitu bentuk isi cokelat, keju, kelapa, mocca, pia kacang hijau dan pia coklat dengan jumlah periode 24 yang berasala dari data yang berjumlah 28 karena ada pada periode ke-2, ke-9, ke-16, dan ke-23 yang tidak berproduksi secara menyeluruh maka data dihilangkan . Evaluasi kartu kendali dari ke-6 kartu kendali yang terbentuk secara keseluruhan tidak terdapat evaluasi berulang hanya satu kendali pembuatan kartu kendali karena kartu yang terbentuk sudah terkendali. Kartu kendali yang terkendali yang dapat mengendalikan produk roti pad CV Spesial Bakery yaitu Kartu kendali Proporsi Roti Isi Coklat yang dapat mengendalikan produk pada gambar 3.2, kartu kendali Proporsi Roti Isi Keju yang dapat mengendalikan produk pada gambar 3.3, Kartu kendali Proporsi Roti Isi Kelapa yang dapat mengendalikan produk pada gambar 3.4, Kartu kendali Proporsi Roti Isi Mocca yang dapat mengendalikan produk pada gambar 3.5, Kartu kendali proporsi Roti Pia Kacang Hijau yang dapat mengendalikan produk pada gambar 3.6 dan kartu kendali Proporsi Roti Pia Coklat yang dapat mengendalikan produk pada gambar 3.7.

\subsubsection{Kecacatan yang Dominan}

Jumlah kecacatn secara keseluruhan yaitu 190 jumlah yang cacat dari jumlah 6 bentuk produksi roti. Secara persentase untuk roti isi coklat $23,16 \%$, isi keju $17,89 \%$, isi kelapa $19,47 \%$, isi mocca $26,84 \%$, pia isi kacang hijau $12,11 \%$ dan pia isi coklat $0,53 \%$. Persentase yang paling dominan untuk kecacatan yaitu pada roti isi mocca dengan persentase 26,84\% dengan jumlah kecacatan 51 dan jumlah produksi 6065 buah roti isi mocca.

\section{SIMPULAN DAN SARAN}

\subsection{Kesimpulan}

Kesimpulan dari hasil dan pembahasan penelitian ini yaitu:

1) Bentuk kartu kendali proporsi yang terkendali data produksi roti yaitu kartu kendali roti isi cokelat

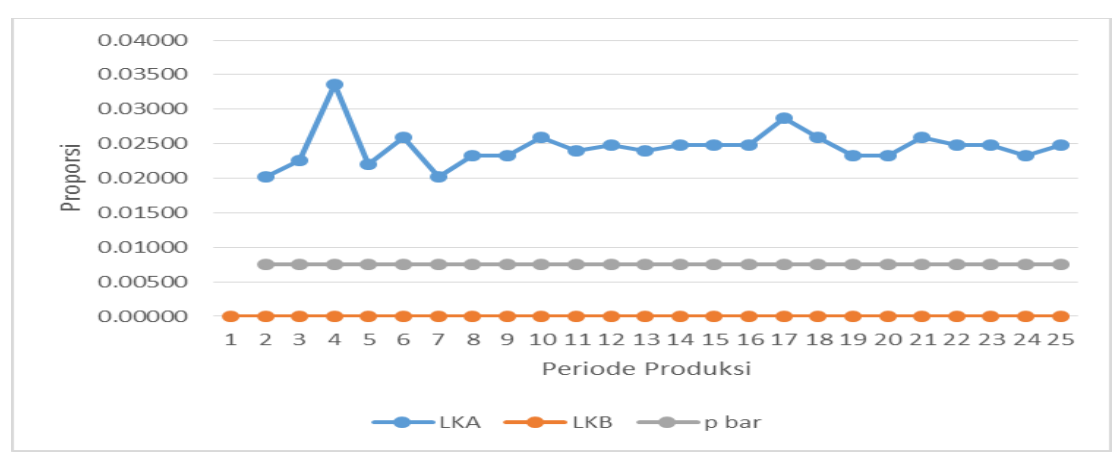

Kartu kendali isi keju, 


\section{STATMAT}

(Jurnal Statistika dan Matematika)
P-ISSN: 2655-3724

STATMAT (Jurnal Statistika dan Matematika), Vol. 1, No. 1, Januari 2019 Halaman: 25-43

@ Prodi S-1 Matematika FMIPA Unpam

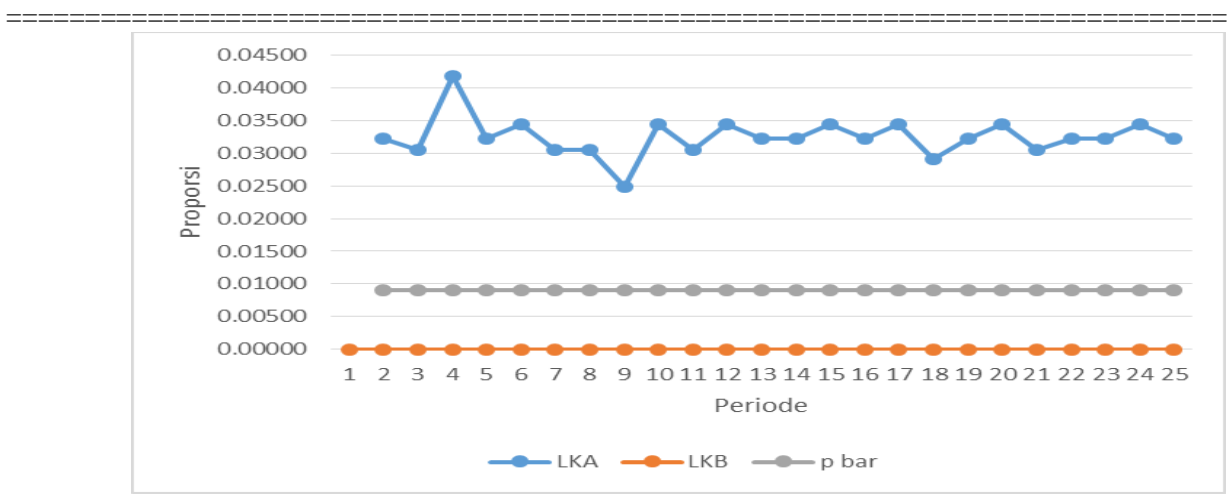

Kartu kendali isi kelapa,

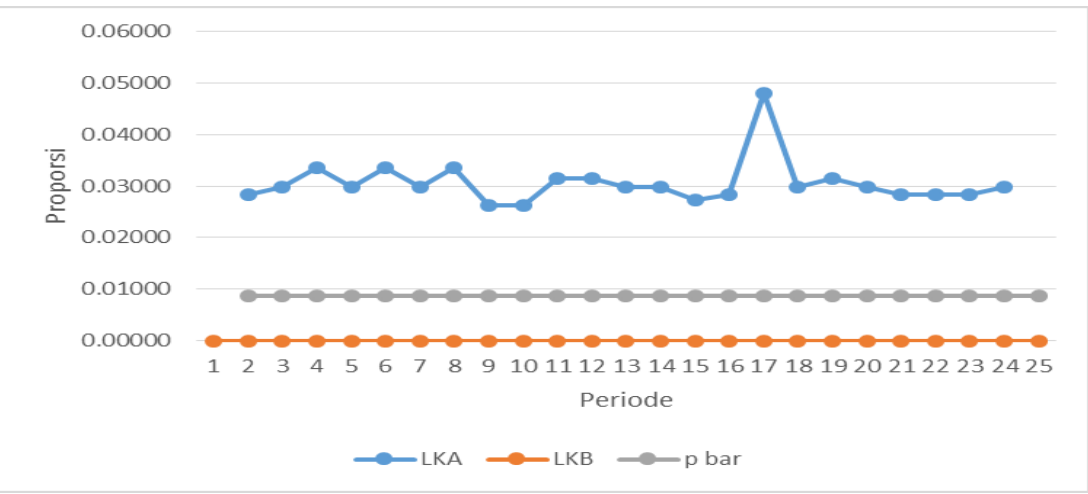

Kartu kendali isi mocca,

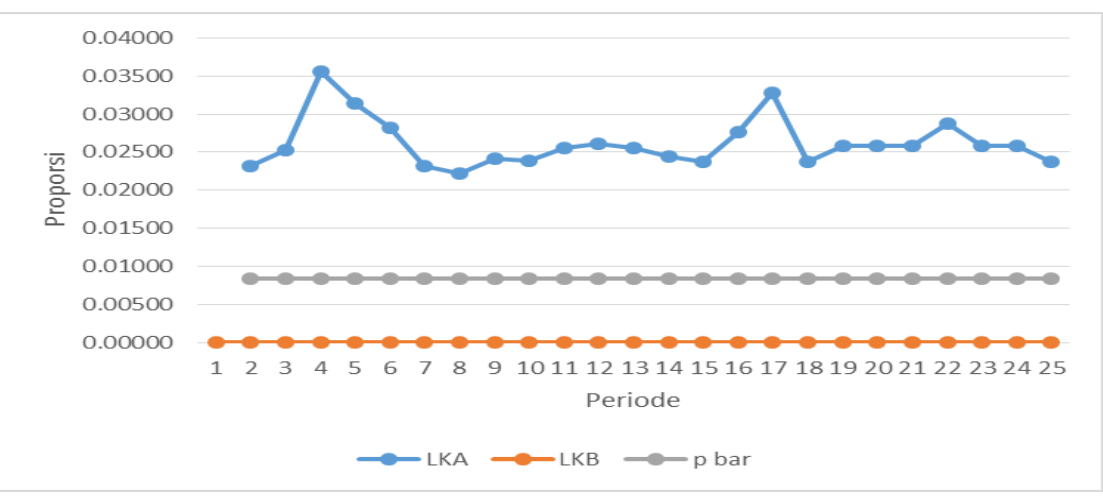

Kartu kendali pia isi kacang hijau,

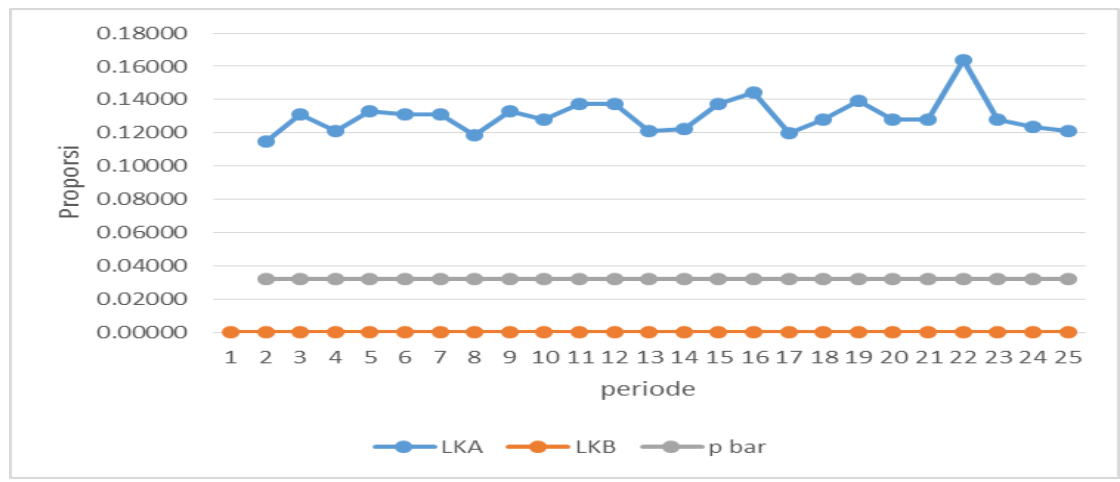




\section{STATMAT}

(Jurnal Statistika dan Matematika)

Dan Kartu kendali pia isi coklat

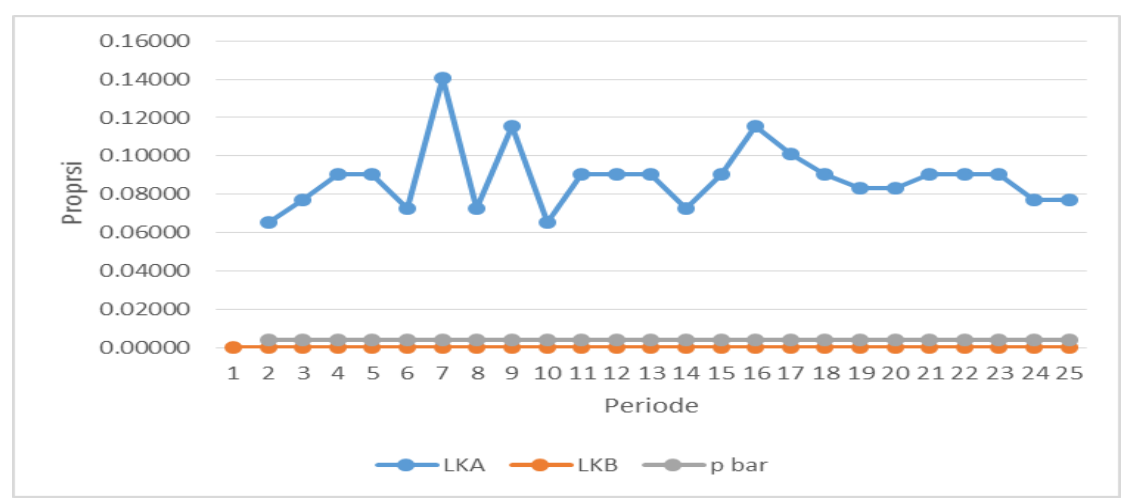

2) Bentuk persentase kecacatan dominan yang terjadi dari produksi roti yaitu pada produksi roti isi mocca denagn persentase $26,84 \%$ dengan jumlah kecacatan 51 dan jumlah produksi 6065 .

\subsection{Saran}

Saran peneliti pada penelitian ini yaitu

1) Saran untuk CV Spesial bakery yaitu untuk dapat mencatat lebih detai setiap proses produksi roti untuk lebih mengetahui proses supaya kualitas semakin lebih meningkat.

2) Saran untuk CV Spesial Bakery dapat menggunakan Kartu kendali supaya lebih terdata dengan lebih baik lagi.

\section{DAFTAR PUSTAKA}

Idris, Iswandi, dkk. "Pengendalian Kualitas Tempe dengan Metode Seven Tools". Jurnal Teknovasi. Volume 03, No.1, http://ejournal.plm.ac.id/index.php/Teknovasi/article/view/80/69, 3 July 2018

Sudjana. 2005. Metode Statistika. Taksiti: Bandung.

Sugiyono. 2012. Statistik untuk Penelitian. Alfabetha: Bandung.

Sugiyono. 2016. Metode Penelitian Kuantitatif, Kualitastif dan R\&D. Alfabetha: Bandung.

Supangat, Andi. 2007. Statistika dalam Kajian Deskriptif, Inferensi, dan Nonparametrik. Kencana : Jakarta.

Nasution, Nur. 2014. Manajemen Mutu Terpadu (Total Quality Management). Ghalia Indonesia: Bogor.

Prihartono, Rudy. 2012. Konsep Pengendalian Mutu. PT Remaja Rosdakarya: Bandung. 